\title{
The Impact Of Service Quality And Trust On Customer Loyalty Through Customer Satisfaction Of Millenial Users Of Bca Credit Card In Jakarta Capital City
}

\author{
Fahmi Rizal $^{1 *}$, Lies Handrijaningsih ${ }^{2}$ \\ ${ }^{1,2}$ Faculty of Economic, Gunadarma University, Jakarta, Indonesia \\ ${ }^{*}$ Corresponding Author: \\ Email: fahmiriza10131@gmail.com
}

\begin{abstract}
.
Banks play important roles in a country's finance. Significant and strategic functions are required to be managed professionally, effectively and efficiently, and properly supporting economic processes in various sectors. Along with the increase needs to spend from consumers, banks as financial companies need to perform competently. This study aims to determine the impacts of service quality and trust in customer loyalty by measuring the satisfaction of Bank BCA credit card millenial customers in Jakarta Capital City of Indonesia. Data collection using primary data with a large sample of 100 respondents aged 26 to 40 years. Primary data was obtained from distributing questionnaires using Likert Scale data on customers who determine satisfaction and loyalty to Bank BCA, and processed using regression analysis and path analysis. The results of this study indicate that service quality, customer value and trust affect customer loyalty stating that they are interested in the services provided by the bank both directly and indirectly to customer satisfaction so that customers show a level of success through customer satisfaction on loyalty.
\end{abstract}

Keywords: Service Qualitity, Trust, Customer Satisfaction, Customer Loyalty

\section{INTRODUCTION}

Banking plays important roles in a country's economy. Significant and strategic functions require banks to be managed in a professional, effective, efficient manner, and to support the implementation of economic processes in various sectors well and healthily. Along with the increasing demand and the more consumptive lifestyle in shopping, banking companies as a financial institution have a central participation.Companies are required to build customers' satisfaction by providing better offers and services. The key to the success of banking management is how the bank wins the hearts of the people so that its function as a financial intermediary goes well. Banks are intermediaries for people and their necessities; the necessity of deep-pocketed people and their necessity to save their money in the form of demand deposits, time deposits, and savings.

The growth of credit card usage in Indonesia has been escalating very rapidly in recent years. A credit card is a means of payment alternative of cash that can be used by consumers to be exchanged for goods and services they want from merchants that can accept payments using credit cards.

Table 1.1.The Growth of Credit Card in Indonesia

\begin{tabular}{|l|l|l|l|}
\hline Tahun & Jumlah Kartu & Jumlah Transaksi & Nilai Transaksi \\
\hline 2009 & 12.259 .295 & 177.817 .542 & 132.651 .567 \\
\hline 2010 & 13.574 .673 & 194.675 .233 & 158.687 .057 \\
\hline 2011 & 14.785 .382 & 205.744 .761 & 178.160 .763 \\
\hline 2012 & 14.817 .168 & 217.956 .183 & 197.558 .986 \\
\hline 2013 & 15.091 .684 & 235.695 .969 & 219.026 .985 \\
\hline 2014 & 16.043 .347 & 250.543 .218 & 250.177 .517 \\
\hline 2015 & 16.863 .842 & 274.719 .267 & 273.141 .964 \\
\hline 2016 & 17.406 .327 & 297.661 .974 & 272.950 .051 \\
\hline 2017 & 17.244 .127 & 319.291 .747 & 288.912 .875 \\
\hline 2018 & 17.275 .128 & 330.145 .675 & 305.201 .319 \\
\hline 2019 & 17.487 .057 & 340.248 .590 & 332.644 .750 \\
\hline
\end{tabular}

$\underline{\text { http://ijstm.inarah.co.id }}$ 
Based on the data presented above, It shows that the growth of credit card usage of bank consumers. The results of the 2020 population census show that the population of productive age (15-64 years) reaches $70.72 \%$ of the total population of Indonesia.. It is believed that "age factor" constructs certain consumer perceptions that affect their satisfaction and loyalty in the ease of transaction. Millennial generation or also known as $\mathrm{Y}$ generation -there is no special demographic in determining this generation group literally- was born in the era of the development of information technology and the world of education, so that they have different characteristics compared to the previous generation.In this study, we can conclude that banks need further review on the character of generations in using their banking products, especially $\mathrm{Y}$ generation so they will be able to create customer satisfaction and loyalty to their products.

\section{LITERATURE REVIEW}

Currently the developments in the service sector, especially banking, are growing rapidly. Service is an activity that can be identified separately, essentially intangible, and a fulfillment of a need and does not have to depend on the sale of other products or services.Banks are required to offer products according to the needs and desires of their customers. By utilizing the products offered, banks must be able to attract the attention of prospective customers not only to introduce, but also to make customers satisfied with their services so that they will be loyal.

\section{Service Quality}

According to Iqbal (2013: 18), quality is the embodiment and or pictures of the results that meet the needs of customers in providing satisfaction. Furthermore, according to Tjiptono and Diana (2012:110), quality is a dynamic condition related to products, services, human resources, processes and the environment that meet or exceed expectations.

\section{Trust}

Trust is an important factor in building commitment between the company and the customer. Trust is the power when a product has certain attributes as all values possessed by consumers, and all conclusions made by consumers about objects, attributes and benefits (Sangadji and Sopiah, 2013: 201).

\section{Customer Satisfaction}

According to Kotler and Keller (2009), satisfaction is a person's feelings of pleasure or disappointment that arise after comparing the performance or results of a product that is thought of against the expected performance or results. Customer satisfaction in the banking service industry according to Nauman and Giel (1995) can be measured based on indicators: perceptions of customers on developed feelings, cost burden, company image, and decisions to use bank services.

\section{Customer Loyalty}

As stated by Kotler, Bowen and Makens (cited by Wijaya and Thio 2007), customer loyalty is defined as the possibility of customer willingness to repurchase and to become a partner for the company. Being a partner means they are willing to buy products or services in larger quantities, providing positive recommendations and willing to inform the company if an error occurs in their service operations. According to Zeithaml (1996) the ultimate goal of the success of a company that establishes relationships with its customers is to form strong loyalty.

\section{RESEARCH AND METHOD}

This study uses two variables, namely, exogenous variables (independent variables) and endogenous variables (dependent variables). The exogenous variables in this study are Service quality (X1), Customer Trust (X2). And endogenous variables in this study are customer satisfaction (Y1) as an intermediary variable, and customer loyalty (Y2) as related variables. 
In this study, the object of research is the credit card services provided by BCA bank. This study learned from customers who use Bank BCA credit cards who are categorized as the millennial and are domiciled in Jakarta Capital City of Indonesia.

\section{SAMPLE}

This study used a non-probability sampling technique. The method chosen is purposive sampling. It is a sampling technique conducted by selecting samples based on certain circumstances, which in this case is the user of Credit Card services provided by BCA bank. Due to the absence of information about the exact amount of the population, therefore the number of sample for this research would be following a theory stated by Lamshow as quoted in Wadiyarti (2017), and the number of sample after the calculation is as many as 100 respondents.

\section{TECHNIQUE OF COLLECTING DATA}

The data used in this research is a quantitative data which were collected through giving out online questionnaires to the respondents. The researcher used an SPSS software for Windows 24.0 version for analyzing technique.

\section{RESULT AND DISCUSSION \\ Simultaneous Influence}

The simultaneous effect of service quality and trust on customer satisfaction (Sub-structure 1)

Table 1. ANOVA Sub-structure 1

\begin{tabular}{|ll|r|r|r|r|c|}
\hline \multicolumn{1}{|c|}{ ANOVA $^{\text {a }}$} \\
Model & & \multicolumn{1}{|c|}{$\begin{array}{l}\text { Sum of } \\
\text { Squares }\end{array}$} & \multicolumn{1}{c|}{ df } & Mean Square & \multicolumn{1}{c|}{ F } & Sig. \\
\hline 1 & Regression & 53.422 & 2 & 26.711 & 10.849 & $.000^{\mathrm{b}}$ \\
& Residual & 238.818 & 97 & 2.462 & & \\
& Total & 292.240 & 99 & & & \\
\hline
\end{tabular}

a. Dependent Variable: Kepuasan_Nasabah

b. Predictors: (Constant), Kepercayaan, Kualitas_Layanan

Ho : There is no combined service quality and trust effect on customer satisfaction.

$\mathrm{Ha}$ : There is a combined service quality and trust effect on customer satisfaction.

Based on the calculation above, the significance number is $0.00<0.05$ so Ho is rejected and $\mathrm{Ha}$ is accepted. This means that there is a joint effect of service quality on customer satisfaction.

Table 2. Summary Sub-structure 1

Model Summary

\begin{tabular}{|l|l|l|c|c|}
\hline Model & $\mathrm{R}$ & R Square & $\begin{array}{c}\text { Adjusted R } \\
\text { Square }\end{array}$ & $\begin{array}{c}\text { Std. Error of } \\
\text { the Estimate }\end{array}$ \\
\hline 1 & $.428^{\mathrm{a}}$ & .183 & .166 & 1.56909 \\
\hline
\end{tabular}

a. Predictors: (Constant), Kepercayaan, Kualitas_Layanan

The value of $\mathrm{R}$ square $\left(\mathrm{r}^{2}\right)$ is 0.183 or $18.3 \%$ (substructure 1 ). In other words, the variability of consumer satisfaction that can be explained by using The service quality variable is $81.7 \%$, while the influence of $81,7 \%$ is caused by other variables outside of this model such as products, prices, and so on.

The effect of service quality, trust and customer satisfaction combined on customer loyalty (Substructure 2)

Table 3. ANOVA Sub-structure

\begin{tabular}{|c|c|c|c|c|c|c|}
\hline \multicolumn{7}{|c|}{ ANOVA ${ }^{\mathrm{a}}$} \\
\hline & & $\begin{array}{l}\text { Sum of } \\
\text { Squares }\end{array}$ & df & Mean Square & $\mathrm{F}$ & Sig. \\
\hline \multirow{3}{*}{$\frac{\text { Mo }}{1}$} & Regression & 89.144 & 3 & 29.715 & 37.650 & $.000^{\mathrm{b}}$ \\
\hline & Residual & 75.766 & 96 & .789 & & \\
\hline & Total & 164.910 & 99 & & & \\
\hline
\end{tabular}

a. Dependent Variable: Loyalitas_Nasabah

b. Predictors: (Constant), Kepuasan_Nasabah, Kualitas_Layanan, Kepercayaan 
Ho : There is no influence of service quality, trust and customer satisfaction combined on customer loyalty.

$\mathrm{Ha}$ : There is an influence of service quality, trust and customer satisfaction combined against customer loyalty.

Based on these calculations, the significance number is $0.00<0.05$ so Ho is rejected and Ha is accepted.

That is, there is an influence of service quality, trust and customer satisfaction in a combination of customer loyalty.

Table 4. Summary Substructure 2

Model Summary

\begin{tabular}{|l|l|l|r|r|}
\hline Model & $\mathrm{R}$ & $\mathrm{R}$ Square & $\begin{array}{c}\text { Adjusted } \mathrm{R} \\
\text { Square }\end{array}$ & $\begin{array}{c}\text { Std. Error of } \\
\text { the Estimate }\end{array}$ \\
\hline 1 & $.735^{\mathrm{a}}$ & .541 & .526 & .88839 \\
\hline
\end{tabular}

a. Predictors: (Constant), Kepuasan_Nasabah,

Kualitas_Layanan, Kepercayaan

The value of R square $\left(\mathrm{r}^{2}\right)$ is 0.998 or $99.8 \%$ (sub-structure 2 ). In other words, the variability of consumer loyalty can be explained by electronic channel banking and customer satisfaction by $99.8 \%$, while the effect of $0.2 \%$ is caused by other variables outside of this model such as products, services, prices, images and so on.

\section{Partial Influence}

\section{Sub-structure 1}

Table 5. Coefficients Sub-structure 1

Coefficients $^{\mathrm{a}}$

\begin{tabular}{|c|c|c|c|c|c|c|}
\hline \multirow{2}{*}{\multicolumn{2}{|c|}{ Model }} & \multicolumn{2}{|c|}{ Unstandardized Coefficients } & \multirow{2}{*}{$\begin{array}{c}\begin{array}{c}\text { Standardized } \\
\text { Coefficients }\end{array} \\
\text { Beta } \\
\end{array}$} & \multirow[b]{2}{*}{$t$} & \multirow[b]{2}{*}{ Sig. } \\
\hline & & $\mathrm{B}$ & Std. Error & & & \\
\hline \multirow[t]{3}{*}{1} & (Constant) & 4.643 & 1.605 & & 2.892 & .005 \\
\hline & Kualitas_Layanan & .062 & .026 & .223 & 2.355 & .021 \\
\hline & Kepercayaan & .146 & .049 & .279 & 2.950 & .004 \\
\hline
\end{tabular}

a. Dependent Variable: Kepuasan_Nasabah

a. Direct influence of electronic channel banking on customer satisfaction.

Ho : There is no effect of electronic channel banking on customer satisfaction. Ha : There is an influence of electronic channel banking on customer satisfaction.

Based on the calculation above, the significance number is $0.000<0.05$ so Ho is rejected and $\mathrm{Ha}$ is accepted. From the results of hypothesis testing conducted, it shows that electronic channel banking has a positive influence on customer satisfaction.

\section{Sub-structure 2}

Table 6. Coefficients Sub-structure 2

\begin{tabular}{|c|c|c|c|c|c|c|}
\hline \multicolumn{7}{|c|}{ Coefficients $^{a}$} \\
\hline \multirow[b]{2}{*}{ Model } & & \multicolumn{2}{|c|}{ Unstandardized Coefficients } & \multirow{2}{*}{$\begin{array}{c}\begin{array}{c}\text { Standardized } \\
\text { Coefficients }\end{array} \\
\text { Beta }\end{array}$} & \multirow[b]{2}{*}{$t$} & \multirow[b]{2}{*}{ Sig. } \\
\hline & & $\mathrm{B}$ & Std. Error & & & \\
\hline 1 & (Constant) & -1.495 & 1.258 & & -1.189 & .237 \\
\hline & Kualitas_Layanan & .032 & .020 & .113 & 1.576 & .118 \\
\hline & Kepercayaan & .140 & .039 & .263 & 3.620 & .000 \\
\hline & Kepuasan_Nasabah & .585 & .076 & .572 & 7.667 & .000 \\
\hline
\end{tabular}

a. Direct influence of electronic service quality on customer loyalty.

Ho: There is no influence of service quality on customer loyalty.

Ha: There is an influence of electronic channel banking on customer loyalty.

Based on the calculation above, the significance number is $0.000<0.05$ so Ho is rejected and Ha is accepted. From the results of hypothesis testing conducted, it shows that electronic channel banking has a positive influence on customer loyalty. 
b. Direct influence of service quality on customer loyalty.

Ho: There is no influence of trust on customer loyalty.

Ha: There is an influence of trust on customer loyalty.

Based on the calculation above, the significance number is $0.000<0.05$ so Ho is rejected and Ha is accepted. From the results of hypothesis testing conducted, it shows that electronic channel banking has a positive influence on customer loyalty.

c. Effect of customer satisfaction on customer loyalty directly.

Ho : There is no direct effect on customer satisfaction on customer loyalty.

$\mathrm{Ha}$ : There is an influence of customer satisfaction on customer loyalty directly.

Based on the calculation above, the significance number is $0.000<0.05$ so Ho is rejected and Ha is accepted. From the results of hypothesis testing conducted, it shows that customer satisfaction has a positive influence on customer loyalty.

Summary

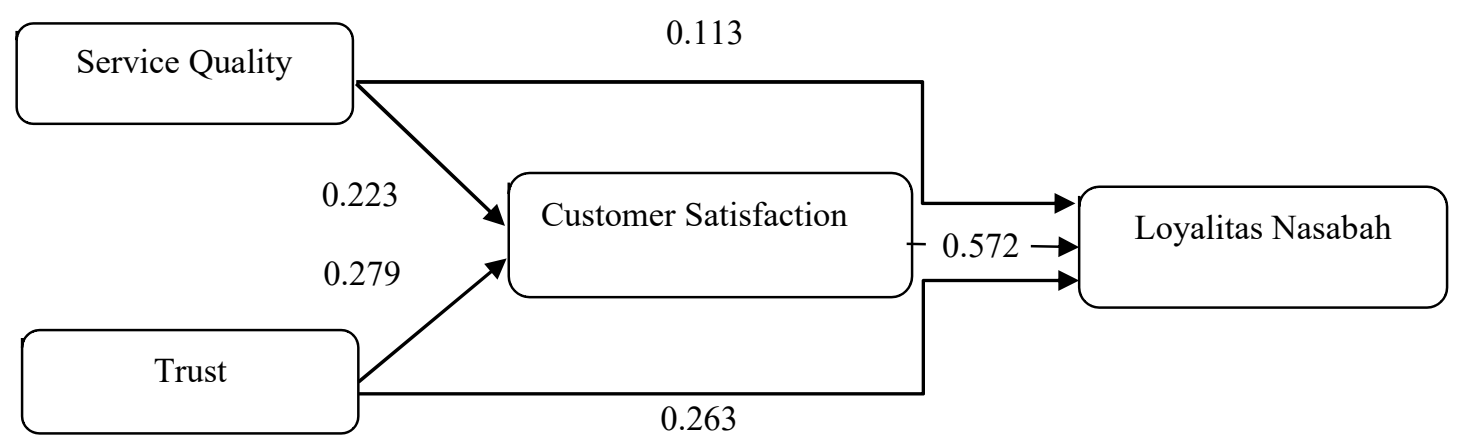

The structural equations for this model are:

Sub-structure 1:

$\mathrm{Y} 1=\mathrm{PY} 1 \mathrm{X} 1+\mathrm{PY} 1 \mathrm{X} 2+€ 1$

$\mathrm{Y} 1=0.223 \mathrm{X} 1+0.279 \mathrm{X} 2+0.017$

Sub-structure 2:

$\mathrm{Y}_{2}=\mathrm{PY}_{2} \mathrm{X}_{1}+\mathrm{PY}_{2} \mathrm{X}_{2}+\mathrm{PY}_{2} \mathrm{Y}_{1}+€_{2}$

$\mathrm{Y}_{2}=0.113 \mathrm{X}_{1}+0.263 \mathrm{X}_{2}+0.572 \mathrm{Y}_{1}+0.002$

a. Direct Effect or DE

To calculate the direct effect or DE, the following formula is used:

1. Effect of service quality variables on customer satisfaction $\mathrm{X}_{1} \rightarrow \mathrm{Y}_{1}=0.223$

2. Effect of service variables on customer loyalty $X_{2} \rightarrow Y_{1}=0.279$

3. Effect of trust variables on customer satisfaction $\mathrm{X}_{1} \rightarrow \mathrm{Y}_{2}=0,113$

4. Effect of trust variables on customer loyalty $X_{2} \rightarrow Y_{2}=0.263$

5. Effect of customer satisfaction on customer loyalty. $\mathrm{Y}_{1} \rightarrow \mathrm{Y}_{2}=0.572$

b. Indirect Effect or IE

To calculate the indirect effect or IE, the following formula is used:

1. Effect of electronic channel banking variables on customer loyalty.

$\mathrm{X}_{1} \rightarrow \mathrm{Y}_{1} \rightarrow \mathrm{Y}_{2}=(0.223 \times 0.572)=0.127$

$\mathrm{X}_{2} \rightarrow \mathrm{Y}_{1} \rightarrow \mathrm{Y}_{2}=(0.279 \times 0.572)=0.160$

c. Total Effect

To calculate the total effect, namely by adding the influence of DE and IE as follows: 
1. Effect of electronic channel banking on customer loyalty.

$\left(\mathrm{X}_{1} \rightarrow \mathrm{Y}_{2}\right)+\left(\mathrm{X}_{1} \rightarrow \mathrm{Y}_{1} \rightarrow \mathrm{Y}_{2}\right)=(0.113+0.127)=0.24$

$\left(\mathrm{X}_{2} \rightarrow \mathrm{Y}_{2}\right)+\left(\mathrm{X}_{2} \rightarrow \mathrm{Y}_{1} \rightarrow \mathrm{Y}_{2}\right)=(0.263+0.160)=0.423$

\section{CONCLUSION}

Based on the results of the research that has been done can be concluded, that service quality and trust has an influence on customer loyalty both directly and indirectly through customer satisfaction. In other words, providing good service and trust can provide bank added value in increasing customer loyalty. In Indonesia the majority of the population is in productive age with very high activity, in this case of course the people needs or facilities that can provide convenience in conducting transactions so that activities can run effectively and efficiently. Service quality and trust can provide convenience for people in transactions. The number of users of credit card is due to the large level of consumption and mobile phone users in Indonesia since all services transaction used echannel banking included credit card. This positive impact that is acquired from service quality and customer staisfaction will be able to raise the customer's loyalty which will force them to trust BCA in handling all of their financial needs

\section{REFERENCES}

[1] Kotler, P. \& Keller, K. (2009). Manajemen Pemasaran. edisi 13 jilid 1. Bob Sabran, Penterj) JaNarta: Erlangga.

[2] Sangadji, E.M., dan Sopiah. 2013. Prilaku Konsumen: Pendekatan Praktis Disertai:Himpunan Jurnal Penelitian. Yogyakarta: Penerbit Andi

[3] Tjiptono, Fandy dan Anastasia Diana.2012. Total Quality Management.Yogyakarta: Andi Offset.

[4] Wadiyarti, Yunisa Muhith. 2017. Faktor yang memengaruhi minat mahasiswa magister manajemen

[5] di Yogyakarta dalam pemilihan karir sebagai enterpreneur. Thesis. Universitas Muhammadiyah

[6] Yoyakarta

[7] Wijaya, Serly dan Sienny Thio, 2007. Implementasi Membership Card Dan Pengaruhnya Dalam Meningkatkan Loyalitas Pengunjung Restoran di Surabaya", Skripsi, Fakultas Ekonomi Universitas Kristen Petra 